\title{
FAT1 wt Allele
}

National Cancer Institute

\section{Source}

National Cancer Institute. FAT1 wt Allele. NCI Thesaurus. Code C51154.

Human FAT 1 wild-type allele is located in the vicinity of $4 \mathrm{q} 35$ and is approximately $139 \mathrm{~kb}$ in length. This allele, which encodes protocadherin Fat 1 protein, plays a role in both cellular polarization and cell adhesion. 